California Western School of Law

CWSL Scholarly Commons

Faculty Scholarship

2016

Re-Designing Law and Lawyering for the Information Age

Thomas D. Barton

Follow this and additional works at: https://scholarlycommons.law.cwsl.edu/fs

Part of the Legal Profession Commons 


\title{
ARTICLES
}

\section{RE-DESIGNING LAW AND LAWYERING FOR THE INFORMATION AGE}

\author{
ThOMAS D. BARTON*
}

\begin{abstract}
This Article analyzes the intersection of three aspects of law, lawyering, and Information Age technology and culture, describing how they disrupt and inhibit one another even as they supply possible opportunities for each to grow and innovate. The Article urges that Information Age challenges to traditional legal institutions and thinking become the foundation for reforms to legal systems and individual laxyering. In embracing changes made possible by emerging technology, the Rule of Law may be strengthened globally and the Preventive/Proactive style of lawyering can be re-invigorated. The Article begins by describing the Preventive/Proactive lauyering ("PPL") style, and offers an example within commercial contracting. The Article analyzes how the adoption of this PPL style has been limited by traditional legal institutions and thinking, described using the metaphor of a container. The effectiveness and cultural acceptability of this containerized legal system is being challenged, however, by Information Age methods and attitudes concerning information and its delivery; the nature of individuals and their social groupings; and the legitimacy and purposes of social control. Emerging Information Age culture, however, is largely compatible with the assumptions underlying PPL. As Information Age technology unfolds, preventive/proactive thinking and methods may not only become more popular in everyday lawyering practice, but also may serve as a model for how traditional legal systems may be helpfully reformed. The Article concludes with a set of design principles by which those reforms may be guided.
\end{abstract}

\section{INTRODUCTION}

[A]s Corporate Counsel I have the unique opportunity to become intensely familiar with a single client. I serve as the liaison

* Louis and Hermione Brown Professor of Law, California Western School of Law. B.A. Tulane University, 1971; J.D. Cornell Law School, 1974; Ph.D. (Law) Cambridge University, 1982. The author wishes to thank the editors of the Notre Dame Joumal of Law, Ethics $\mathcal{O}^{\circ}$ Public Policy, and the participants of the Symposium on the Preventive and Positive Rules of Law, Ross School of Business, University of Michigan, June 25-26, 2015, for their most helpful comments and suggestions on this manuscript. 
between the legal department and top management of Novartis Seeds. This relationship permits me to provide better legal services to my client, as I can tailor solutions to certain idiosyncrasies of the organization and the industry that might not be apparent to outside counsel. My proximity to the client also facilitates proactive legal solutions both through a superior vantage point and educational opportunities made possible through close contact. ${ }^{1}$

-Sue McCutcheon

Sue McGutcheon summarizes the ideal role of the business lawyer. Her effectiveness and professional satisfaction derive from several ideas that any lawyer, in-house or external counsel, could readily adopt: become intensely familiar with the client; communicate broadly as a liaison between business and legal communities; and tailor particular solutions to the needs and goals of the client. Slightly broadened, McCutcheon also reveals the outlook and basic methods of Preventive/ Proactive Law ("PPL") ${ }^{2}-$ observe closely the facts and contexts of client risks and goals; inquire and listen well; understand systemically; educate and advise pragmatically as well as legally; and set up feedback channels to learn from mistakes and spot new opportunities.

But the PPL approach is not necessarily easily understood or practiced, even sixty years after its first articulation. ${ }^{3}$ Familiarity and good communications often remain elusive. Timothy $P$. Terrell describes

1. Sue McCutcheon, Corporale Counsel, 43 Advocate 15, 15 (2000).

2. For an overview of Preventive/Proactive Law and its relationship to problem solving and social relationships, see Thomas D. Barton, Preventive Law and Problem SolvinG: LAwYering for the. Future 1-26 (2009). "Preventive Law" as a distinct approach to lawyering was first formulated in 1950 by Louis M. Brown. Lous M. Brown, Preventrve LAw (1950). Brown's work was carried forward by other lawyers and academics, especially Professor Edward A. Dauer, with whom Brown collaborated in the treatise Planning by Lawyers: Materials on a Nonadversarial Legal Process (1978). As developed by Brown and Dauer, Preventive Law focuses on the techniques and professional responsibility of a practicing lawyer when engaging with clients as an advisor and planner, rather than as an advocate. Primary in that approach are the ideas of regular meetings with clients and the development of checklists so that business and life events can be undertaken with minimal risk of problems. See, e.g., Louis M. Brown, Another Dictionary Definition of Preventive Law, 42 J. St. B. CAl. 867 (1967); Louis M. Brown, Legal Audil, 38 S. CAl. L. Rev. 431 (1965). "Proactive Law seeks ways to use the law to create value, strengthen relationships and manage risk." Nordic Sch. of Proactrve LAw, http://www.proactivelaw.org/ (last visited Apr. 13, 2015). Growing out of Preventive Law,

Proactive law seeks a new approach to legal issues in business and society.

Instead of regarding law as a constraint that companies and people in general need to comply with, a cost factor, an administrative burden, or-at best-a means to protect one's own or somebody else's interests against harmful behaviour of others, proactive law considers law as an enabling instrument to create success and foster sustainable relationships.

Gerlinde Berger-Walliser, The Past and Fulure of Proactive Law: An Overview of the Development of the Proactive Law Movement, in Proactive Law in a Business Environment 13, 16 (Gerlinde Berger-Walliser \& Kim Ostergaard eds., 2012).

3. See Z. Jill Barclift, Preventive Law: A Strategy for Internal Corporate Lawyers to Advise Managers of Their Elhical Obligations, 33 J. Legal Prof. 31, $31 \mathrm{n} .3$ (2008) ("In the 1950s preventive law was introduced as a way of practicing law, but it has not been affirmatively adopted by the majority of practicing lawyers. This is perhaps due to the belief by some lawyers that clients are unwilling to pay for preventive lawyering, or that it is not the kind 
some inhibiting tensions, which again could apply to any business lawyer:

The general counsel has one foot planted firmly in the shifting, treacherous terrain of the law, and the other planted just as firmly in the oozing swamp of business. The result is always challenging. Every general counsel teeters one way and then the other in an endless effort to remain standing. The natural response would be to bring one's feet together more securely in one world or the other. $^{4}$

That natural response, to live exclusively and comfortably in either business or law, is not an option for most lawyers. The quest for balance between these two worlds is inevitable, if attorneys are to be effective. Further, the struggle can be valuable in itself. As Terrell points out, an attorney who conscientiously grapples with the relationship displays integrity to the client, which inspires trust in the attorney-client relationship and contributes ultimately to success for both the business and the lawyer. ${ }^{\circ}$

Terrell's outlook is praiseworthy. Reconciling the social and economic world with the legal system in meaningful, productive, and humanistic ways is an important part of the PPL heritage. But can such efforts, however inevitable, be made less necessary? Heroic struggles punctuate individual lives as well as human history; they sharpen values as well as build identity and character. Sometimes, however, an environment can and should be redesigned to render such struggles less onerous. $^{6}$ This Article explores the possibility that the Information Age has supplied lawyers and the legal system the tools for finding better, more stable bridges to the social and economic worlds of their clients; but that those same Information Age disruptions have also created an imperative for beginning that legal system re-design. ${ }^{7}$

The tension between connection and separation in the attorneyclient relationship, and between the law generally and everyday life, will never fully go away. In engaging some problems, a strongly detached, legal rule-centered approach will be paramount to protect individual

of lawyering that is traditionally emphasized in law school. Perhaps, lawyers also perceive preventive law practices to be not as rewarding as pursuing a lawsuit.").

4. Timothy P. Terrell, Professionalism as Trust: The Unique Internal Legal Role of the Comporale Generul Counsel, 46 EMORY L.J. 1005, 1005 (1997).

5. II. at 1006.

6. Sep B.F. Skinner, Bryond Freedom and Digntiy 1-3 (1971) (urging development of a technology of behavior).

7. See M. ETlian Katsh, LaW in a Digrtal Wori.l) 6-7 (1995) [hereinafter KATSH, Digiral. WORLD] ("[C] hange is linked to our use of new information technologies. These new information technologies are particularly relevant to law because law is oriented around information and communication. Whatever definition one gives to the law ... it is always concerned with information."); M. EWHAN KATSH, THE: El.ECIRONIC MEDLA AND THIF. Transformation of LuW 9 (1989) [hereinafter Kitsit, El.Fcironic Mridi] ("The introduction of new forms of communication that possess different qualities will not simply extend trends that are associated with print. The electronic media are not to be considered merely as more powerful versions of print. They have different mechanisms for transmitting and processing information, some of which will pressure the law to change course and become a different and not simply a more efficient institution."). 
rights or a collectively free society. A distanced, rights-based objectivity may be exactly why a client engages a lawyer, or why a lawyer is willing to represent a client. ${ }^{8}$ For other problems, however, legal rules and professional traditions need not, and should not, drive such a strong wedge between attorney and client. Mutually reinforcing communications and flexible, collaborative problem solving methods may be crucial to their resolution or prevention. This Article seeks to deepen our understanding of this distinction, and also reveals why a growing proportion of business and social problems are especially open to being addressed by more integrative, connective legal methods like those articulated in PPL.

When observing the legal professional's balancing act against the backdrop of unfolding Information Age technologies, the interplay of human problems and procedures for their resolution becomes complex. Legal systems are not immune to innovations that are both disruptive and the impetus for creativity and reform. ${ }^{9}$ At first blush, recent technological and informational disruptions appear more prominent, seeming to push the realms of law and social-economic life yet further apart. But if so, what repercussions may follow for businesses, lawyers, and society generally? Will growing obstacles to accessing the law-intellectually, financially, or navigationally-at some point prompt the urge to abandon legal methods altogether in favor of more efficient market or technological alternatives? Should the law seek to stem such movements, or instead seek to re-design itself so as to harness the structural possibilities made available by the revolution in virtually cost-free information?

Skepticism about lack of value-contribution by the legal system is already surfacing in client demands that attorneys cut their costs, ${ }^{10}$ and in efforts to find fully automated approaches to document production. ${ }^{11}$ Such efficiency pressures surrounding legal services are significant, but may also signal far deeper concerns for Western liberal concepts of the Rule of Law-concerns that are not simply academic, but have profound implications for everyday economic and civic life. In leaving behind the Industrial era, emerging globalizing culture may be sharing new visions:

- about information and its delivery: how it is gathered, collated, classified, assessed, and shared;

- about people. the nature of individuals and their social groupings; and

8. Interview with Yana Welinder, Legal Director, Wikimedia Foundation, in San Diego, Cal. (May 5, 2015).

9. See generally Richard Susskind, TOMORRow's Lawyer: An Introduction to Your Future 39-49 (2013). In his fine book, Richard Susskind describes and analyzes a comprehensive list of current and coming reforms in the delivery of legal services in response to "disruptive legal technologies."

10. Id. at 4-5 (explaining clients are increasingly pressuring attorneys to deliver their services with greater efficiency, leading to significant innovations). See also David Orozco, The Use of Legal Crowdsourcing ("Lawsourcing") to Achieve Legal, Regulatory, and Policy Objectives, 53 Ам. Bus. L.J. 9 (2014).

11. Susskind, supra note 9 , at 27. 
- about order and control: its methods, legitimacy, and purposes.

Along these and other dimensions-communications, technology, and socio-economic relationships-the world is celebrating denser, more frequent connections. And yet the legal system historically seeks separation, self-protecting its arm's length distance from social and economic goals through constraints on legal professionals and their methods. Neither business, nor the law, nor Western political values can forever afford those historic levels of detachment. A fully "separationist" legal system will become increasingly inefficient, and culturally remote, relative to problem-solving alternatives that better harness Information Age connectedness. If people respond by clutching at "non-legal" procedural or market innovations that seem more accessible or culturally progressive, will those methods entail unintended consequences? What may be the effects on economic stability as well as dynamics? More deeply, what may the implications be for the values that underpin Western law-individualized freedom, tolerance and protection of diversity and human dignity, and the stability of relationships through both choice and accountability?

Even more important than identifying this possibility is asking whether, and how, the law could right itself. Can it find ways to embrace and grow from the opportunities offered by Information Age technologies? To retain its effectiveness as well as cultural centrality, the law must explore methods for stronger social and informational connections, even while it retains the capability of separating itself when necessary.

At least a starting point is available. This Article urges overlap between the ideas and goals of PPL, and the agenda for legal system reform. Expanded to suit the breadth of new challenges, PPL may serve as a model not just for individual attorneys in serving their clients, but also for the legal system to re-design itself toward stronger, yet thoughtful, engagement with emerging patterns of communications and social integration. ${ }^{12}$ This Article urges development of principles by which legal re-design might be guided, the skeletal beginnings of which are offered at the Article's conclusion. Any such starting point is not only unproven, but carries the values of its creator. The hope, however, is that the list of guiding principles sparks dialogue about the enterprise as well as research of its particulars.

Part II below introduces the separation of law from business, and lawyer from manager. It traces the tendency of the legal system to seclude itself inside a container of its own making - a container whose walls are difficult to penetrate by untrained users, and to which lawyers are tethered. That self-imposed detachment may not long endure, however-or at least not to its traditional extent. As Information Age

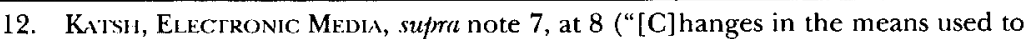
communicate information are important to law because law has come to rely on the transmission of information in a particular form. Law does not simply consume or produce information; law structures, organizes, and regulates information. The effectiveness and operation of law depends on controlling access to some information and highlighting or directing attention to other information."). 
technology and methods penetrate deeper into everyday business life and social communications, the historic legal container of the Enlightenment and Industrial periods may not fully hold.

Part III imagines some opportunities: principles by which the legal system might be redesigned to evolve toward Information Age conditions. Those possibilities grow from reflection about PPL thinking, methods, and evolution. The differences between PPL and traditional lawyering-PPL's stronger interdisciplinary integration and better communication, for example-may serve as a model for how the legal system in general might better accommodate itself to fast-changing cultural attitudes and practices about the creation, classification, and sharing of information. To address at least some problems, law can combine legal rules, markets, social norms, and even the design of products or "architecture" of physical environments. ${ }^{13}$ A legal system that becomes more open, pragmatic, and interconnected will then favor PPL thinking and skills-prompting their further evolution and stronger acceptance. A virtuous cycle of refinement may begin. PPL may thus be an idea whose time has come, hand-in-hand with a legal system re-designed for the Information Age.

\section{Constructing and De-Constructing the Legal Container}

As I have described elsewhere, the law has traditionally understood its significance, authority, and legitimacy through concepts of separation rather than connection. ${ }^{14}$ As a system, it seeks transcendence rather than intimacy: "a government of laws, rather than people"15 that blindfolds justice so as to preserve its role as a crucial defender of liberty and a check on government overreaching. Further, in the Western

13. Lawrence Lessig speculates that social norms, the market, and "architecture" i.e., the "physical constraints that set the terms on which we experience real space"-may become important supplements to formal legal norms in the future of legal design. Lawrence Lessig, The Place of Cyberlaw, in The Place of LAw 131, 135 (Austin Sarat et al. eds., 2006) ("Modern regulation-modern law-is the choice among these different modalities of constraint. Modern regulation is the pragmatic discipline of selecting the tool, or mix of tools, that best brings about the desired social end."). See also SkinNer, supra note 6 (discussing environmental design as a crucial shaper of human behavior); Thomas D. Barton, Common Law and Ils Substitules: The Allocalion of Social Problems to Allernative Decisional Institutions, 63 N.C. L. REv, 519 (1985) (providing an analysis of alternative methods of addressing legal problems).

14. See generally Thomas D. Barton, Troublesome Connections: The Law and Post-Enlightenment Cullure, 47 EMORY L.J. 163, 164-65 (1998) (tracing the emergence of "cultural" and "constitutive" dilemmas for the law, as society enters the Post-Enlightenment era).

15. References to the Rule of Law are legion, both as understood in the West and elsewhere. "The principles of the rule of law, as recognized in developed Western systems, generally include the familiar requirements that law be rule-like so far as appropriate, that it be clear ... and that it generally be prospective." Robert S. Summers, The Principles of the Rule of Law, 74 NOTRE Dame L. Rev. 1691, 1691 (1999) (footnote omitted). For a comparison of its differing cultural interpretations, see ASIAN DISCOURSES ON THE Rule of Law: Theories and Implementation of Rule of Law in Twelve Asian Countries, France, and the U.S. (Randall Peerenboom ed., 2004). For a discussion of the Enlightenment roots of Rule of Law ideas and their challenge in the Post-Modernist era, see Francis J. Mootz III, Is the Rule of Law Possible in a Postmodern World?, 68 WASH. L. Rev. 249 (1993). 
liberal tradition, the law is said to be "non-teleological"; in other words, it typically hesitates to articulate overriding social goals or end purposes. ${ }^{16}$ Objectives are instead left to be formulated by other branches of government or by private clients. PPL, by contrast, not only takes off the blindfold to look directly at clients, but takes a wide-angle lens to examine and understand their broader environments and firmly accepts the idea of identifying and facilitating their goals.

The separation of the law from those it serves is typically described, and praised, under the idiom of "independence." One traditionallyoriented lawyer characterized that detachment as a fundamental quality of the lawyer's social role:

Goal XI of the American Bar Association's mission statement charges the Association and its members: To preserve the independence of the legal profession and the judiciary as fundamental to a free society. Why is it that a free society requires the independence of lawyers and judges? No democracy can survive unless someone stands between the individual and the abuse of authority. Within the separation of powers doctrine, that is what lawyers and judges do in this country .... [L] awyers and judges ... preserve individual rights, equal protection, and the rule of law ... . Loyalty demands independence from any competing influence, whether economic, political, or otherwise. ${ }^{17}$

This self-understanding of lawyers as builders and guardians of an independent legal counterforce is based in the structure of government as well as intellectual history. Legal detachment is, of course, embedded in the constitutional separation of powers envisioned by the creation of an independent judiciary. ${ }^{18}$ But separationist Western ideas of the Rule of Law also evolved from Enlightenment philosophy, with roots deeper yet in the scientific method (developed by a lawyer, Lord Chancellor Francis Bacon) $)^{19}$ and the rational skepticism of Rene Descartes. ${ }^{20}$

Western culture generally ... has strikingly preferred the ideas and values of separation over those of connection. Ideas implying separation-concepts like freedom, formal equality, individuality, detachment, segmentation, and abstraction-have influenced legal processes as well as prevailing social images of human relationships. The competing ideas and values of connectednessconcepts like relationship, belonging, loyalty, community, solidar-

16. See Thomas D. Barton, Liberalism and Theories of Adjudicaliom, 28 B.C. L. Rev. 625, 629-32 (1987) (discussing Roberto Mangabeira Unger, Knowi.fogr. and Politics 76-77 (1975)).

17. Jack F. Dunbar, Multidisciplinary Practice Transhated Means "Let's Kill All the Lave yers," 79 Mich. B.J. 64, 64 (2000).

18. U.S. CONST. art. III.

19. Francis Brocom, WIKlPEDlA, http://en.wikipedia.org/wiki/Francis_Bacon (last visited Apr. 13, 2015).

20. Colin E. Gunton, Enlightenment and Alienation: An Essay Towards a Trinitarian Theolocy 3 (1985). See alio Alasdair Macintyre, After Virtue: A Study in MORAL ThEORY 34-48 (2d ed. 1981). 
ity, particularity, and contextual understanding-have been secondary to those of separation. ${ }^{21}$

In its quest for reason, autonomy, objectivity, precision, and control, ${ }^{22}$ Enlightenment legal as well as scientific thought adopted a strategy of divide and conquer. ${ }^{23}$ It promoted the intellectual and organizational disconnection of humans from nature; ${ }^{24}$ individuals from social role; 25 individuals from other individuals; ${ }^{26}$ fact from value; ${ }^{27}$ reason from emotion; ${ }^{28}$ law from morality; ${ }^{29}$ and even the law from the state. ${ }^{30}$ Detachment of the mind from mundane physical existence was said to free reason to discover a pure and transcendent truth. ${ }^{31}$

21. Barton, supra note 14, at 163 .

Some commentators explain the historical privileging of separation over connection as a consequence of gender differences. See, e.g., Trina Grillo, The Mediatiom Allernative: Process Dangers for Women, 100 YALE L.J. 1545, 1547 (1991); Linda C. McClain, "Alomistic Man" Revisited: Liberalism, Connection, and Feminist Juristrudence, 65 S. CAL. L. Rev. 1171 (1992); Robin West, Jurisprudence and Gender, 55 U. CHI. L. Rev. 1 (1988). Others explain it as the inherent tendency of liberal political philosophy. See, e.g., Michael J. Sandel, Liberalism and the Limits of Justice (1982); Roberto M. Unger, Knowlenge and Polmas (1975); Peter Gabel, The Phenomenology of Rights-Consciousness and the Pact of the Wilhdrawn Selves, 62 Tex. L. Rev. 1563 (1984). Still others deem it to result from the interplay of gender differences and liberalism. See, e.g., Jennifer Nedelsky, Violence Against Women: Challenges to the Liberal Stale and Relational Fominism, in Nомоs XXXVIII: Polmtical Order 454, 455-56, 462 (Ian Shapiro \& Russell Hardin eds., 1996) [ ]; Suzanna Sherry, Civic Virtue and the Feminine Voice in Constilutional Adjudication, 72 VA. L. Rev. 543, 544-45, 584 (1986) . . .

Id. at 163 n.1.

22. Enlightenment philosophy did not evolve in a vacuum. It moved hand in glove with the prevailing information technology. "The linearity, precision, and uniformity of the arrangement of movable types are inseparable from [the] great cultural forms and innovations of Renaissance experience." Marshall MCLuhan, Understanding Media: The Extensions of MAN 172 (1964).

23. Thomas D. Barton, Law and Science in the Enlightenment and Beyond, 13 Soc. EPISTEMOLOGY 99, 100 (1999).

24. Drucilla Cornell, Toward a Modern/Postmodern Reconstruction of Ethics, 133 U. PA. L. REv. 291, 308-09 (1985).

25. Id. at 291-92, 358 .

26. Mary Ann Glendon, Rights Talk: The Impoverishment of Political DisCOURSE $47-48$ (1991).

27. Thomas L. Shaffer \& Mary M. Shaffer, Character and Communily: Rispetto as a Virtue in the Tradition of Italian-American Lauyers, 64 NOTRE DAME L. REv. 838, 840 (1989).

28. Lynne N. Henderson, Legality and Empathy, 85 MrCH. L. Rev. 1574 (1987).

29. Robin West, Natural Law Ambiguities, 25 ConN. L. Rev. 831, 834-35 (1993); see also Jonathan Edward Maire, The Possibility of a Christian Jurisprudence, 40 AM. J. JURIs. 101, 128 (1995).

30. Arthur S. Miller, Myth and Reality in American Constitutionalism, 63 TEx. L. Rev. 181, 183 (1984) (book review).

31. Gunton, supra note 20 , at 4 . As McLuhan writes,

Perhaps the most significant of the gifts of typography to man is that of detachment and noninvolvement-the power to act without reacting. Science since the Renaissance has exalted this gift which has become an embarrassment in the electric age, in which all people are involved in all others at all times.

MCLUHAN, supra note 22, at 173. 
Little wonder, then, that the legal system constructed a strong container for itself, largely detaching from the world. ${ }^{32}$ Once built, it is natural that its operators-lawyers-would ensconce themselves inside, maintaining intellectual, organizational, procedural, and professional barriers to support the walls of the legal container. These container walls are comprised of at least the following layers, which reinforce one another as though laminated together to assure a stronger barrier:

- A specialized vocabulary arranged in dense prose that can become virtually unreadable for the untrained public;

- Transcendent legal rules designed for universal obedience, but whose authoritative interpretation is reserved exclusively for expert judges;

- Formalized legal procedures that both limit information ${ }^{33}$ and require savvy navigational skills;

- Professional responsibility norms that tether attorneys closely to the container itself; and

- A detached, self-referencing rationality that measures the validity, success, and justice of legal decisions against the very rules generated from inside the container.

Can such barriers survive a culture that is fast being re-shaped by the informational transparency and participatory ethic of the Internet? Are the epistemological and ontological assumptions of the Enlightenment, together with Industrial packaging and distributional methods, sustainable in Information Age legal systems? ${ }^{34}$ Those are the overriding issues to be addressed in this Article, layer by layer.

\section{A. Layer One: Lauyyers and Clients}

Importantly, the walls of the traditional legal container limit permeability in both directions. They make it hard for users to get inside, i.e., to access, comprehend, and use the law. But the walls also impede the legal system itself from integrating its methods with other problemsolving devices: markets, social norms, human emotions, technical fixes, and the architecture of physical environments. The walls also confine the lawyers trained and operating from within, owing to the rigor of the

32. KATSH, El.FCTRONIC MEDIA, supm note 7, at 231 ("Modern law is characterized, first, by a perspective on the individual that is lacking in most premodern systems. Second, modern Western systems of law rely much more heavily on abstractions than other legal systems. Both of these qualities contributed to the development of fundamentally important characteristics of liberal legal systems, such as the protection of legal rights and fundamental liberties.").

33. Id. at 53 ("Law ... is a means of resolving disputes that also consciously restricts and limits the kind of information that is employed in reaching a decision. By agreeing to use law to settle their dispute, the parties agree that only information relevant to the appropriate rule may be used.").

34. McLulinN, supra note 22, at 173 ("In the 'implosion' of the electric age the separation of thought and feeling has come to seem as strange as the departmentalization of knowledge in schools and universities. Yet it was precisely the power to separate thought and feeling, to be able to act without reacting, that split literate man out of the tribal world of close family bonds in private and social life."). 
intellectual construct of the law, the intensity of professional legal education, and the ethical norms surrounding the profession.

The legal and professional framework through which attorneys naturally come to understand and respond to human problems is both powerful and general, a mass that results in significant inertia. Hence the perpetual straddling that is required of lawyers as they try to keep a foot both inside, and outside, the container. Professional ethics form a special layer of the historical legal container, making it difficult for attorneys to stray too far from its confines. Viewed from inside the container (within which these ethical rules are generated, interpreted, and enforced), the norms are both essential and sensible. But they can also cause attorneys to resist PPL methods. For example, Sally R. Weaver nicely analyzes the professionalism dilemmas posed for business lawyers (and especially in-house counsel), as they bring legal advice to the business community. ${ }^{35}$ Corporate counsel, she explains, often "assume responsibilities in the organization that exceed, and differ from, those of the typical attorney-client relationship. Corporate counsel may serve as members of the board of directors, as officers of the corporation, and as members of executive management committees; in addition, they may have compliance responsibilities that are not strictly legal in nature." ${ }^{6}$ That would be a good thing, she acknowledges, but the pathway is treacherous:

Notwithstanding the perceived value of this expansive role to both the corporate counsel and to the organization, the role may impose an unacceptable risk of conflict of interest and the perception (if not the reality) of interdependence between the organization and the corporate counsel. This broader role also increases the likelihood that the organization will lose the benefit of the attorney-client privilege. ${ }^{37}$

Weaver reflects separationist instincts that are built up within the traditional legal container, a felt need to keep a professional distance from the client. ${ }^{38}$ Several norms are embedded in her language above, all warning of the dangers of getting too close: conflicts of interest, lack of professional independence, and professional incompetency in compromising the proper attorney-client relationship. Hence prudence seems to suggest that information flows between lawyer and client be

35. Sally R. Weaver, Ethical Dilemmas of Corporate Counsel: A Struclural and Contextual Analysis, 46 EMORY L.J. 1023 (1997).

36. Id. at 1027.

37. Id.

38. While corporate counsel confront professional responsibility hurdles in expanding their role with business clients, attorneys serving clients of limited incomes face the opposite problem. Efforts to make legal services more affordable by "unbundling" legal services-having attorneys play only a limited role in representing clients by hiving off to the client tasks of fact development or form completion, for example-also encounter professional responsibility obstacles. For a helpful overview of the idea and ethical considerations surrounding unbundled legal services, see Ruth S. Stevens, Unbundling of Legal Services: Selected Resources, 89 MicH. B.J. 54 (2010). 
carefully channeled and constrained.$^{39}$ Informal information learned by the close proximity to a client, says Weaver-through "back-channel[s]" or at the water-cooler-can lead to expectations that may require an attorney to step out of traditional roles. ${ }^{40}$ But this is precisely the kind of information-gathering that PPL encourages. Importantly, the information gathering itself is not prohibited by professional ethics, ${ }^{41}$ although it does indeed carry duties. The PPL lawyer must be especially sensitive to the ethical rules as they venture further from the container; and the further they stray, the more they must be willing to accept new responsibilities. As Weaver recognizes, learning "back-channel" information may demand a more proactive approach by the lawyer, requiring the attorney to initiate discussion about a concern rather than waiting to be asked for an opinion. ${ }^{42}$

There is the rub. Many lawyers are uncomfortable with the implications of having to become proactive, because it entails not only a mentality beyond the typical professional self-understanding, but also systems analysis ${ }^{43}$ and planning skills ${ }^{44}$ that are likely beyond their formal training. ${ }^{45}$ For lawyers who have embraced PPL methods, however,

39. See Edward A. Dauer, The Role of Cullure in Legal Risk Management, 49 ScidididsVLAN SICD. L. 93, 98-101 (2006) (discussing the importance of understanding the cultural contexts in which legal problems arise).

40. Weaver, sujm note 35 , at 1028.

41. As stated in the Momit. Rulfs of Prof. Condtci r. 2.1 (Ам. Bak Ass'v 2013), "In representing a client, a lawyer shall exercise independent professional judgment and render candid advice. In rendering advice, a lawyer may refer not only to law but to other considerations such as moral, economic, social and political factors, that may be relevant

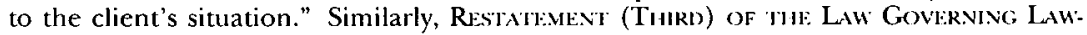
YI:RS \$ 94(3) (AM. L.An I.vSr. 2000) says, "In counseling a client, a lawyer may address nonlegal aspects of a proposed course of conduct, including moral, reputational, economic, social, political, and business aspects."

42. Weaver, sufrr note 35 , at 1028 .

43. Sep Dauer, sufm note 39, at 98-99 (doing "root cause analysis" of "systems failures").

44. As Jill Barclift remarks, "Preventive Law encourages lawyers to embed themselves into client matters, intervene before a crisis arises, and map a plan for legal risk." Barclift, sufra note 3 , at 33 . Furthermore,

Internal corporate law practice is proactive. In their role as proactive advisors, internal corporate lawyers work with managers to design business transactions for legal compliance. ... In addition to evaluating the legal issues in a business transaction, internal corporate lawyers assist clients in assessing the feasibility of a business deal in light of legal obstacles and work to design solutions. The internal corporate lawyer must appreciate human nature and the corporate culture. To accomplish these tasks, internal corporate lawyers must understand client goals and the motivation for business decisions. Thus, internal corporate lawyers must work collaboratively and proactively to identify legal risks and design a plan for managing such risks. A challenge for internal lawyers is not only the identification of legal risk but also the communication of legal risk to corporate managers.

Id. at 39 (citations omitted).

45. See Thomas D. Barton, The Morles and Tenses of Legal Problem Solving, and What to Do Aboul Them in Legal Educulion, 43 CAL. W. L. Rev. 389 (2007). Legal education focuses strongly on the analysis of legal rules, set in the context of a "past tense" proceeding: courts passing judgment on evidence attempting to reconstruct human actions so as to determine liability ("who is to blame for this injury?"). In the past thirty years, the "present tense" mode of legal problem solving has been brought in: training in the consensual 
the greater effort and heightened sensitivities are rewarded through better client service and outcomes. As explained by Edward A. Dauer,

The objective of Proactive Law is the management of legal risk through identifying, anticipating and planning for it in advance. Its economic premise is straightforward: legal disputes and legal liabilities generally cost less to avoid at the outset of a relationship or a transaction than they cost to cure once they have arisen .... We can often reduce legal risk by predicting and then shaping or accounting for the ordinary, well-meaning, everyday behaviors of the people who touch or are touched by the events. ${ }^{46}$

Other points of departure further distinguish PPL. ${ }^{47}$ Traditional legal thinking leans toward values of stability and reliability in decisionmaking; it stresses procedural regularity, and its analytical methods pare away details of context and underlying human relationships to reveal the essential elements of legal rules. PPL, by contrast, shares much in common with the strategic thinking of business managers. Compared to traditional legal thought, PPL:

- is more goal-oriented and pragmatic about the methods of decision-making;

- is more comfortable with outcomes that are particular and provisional rather than universally-applicable and permanent;

- expands, rather than reduces, the contexts in which problems and goals are viewed, seeking to understand the broader systems that may influence changing environments and how people behave within those settings;

- maintains a communication style that is multi-directional with designed feedback loops, rather than channeled and hierarchical;

- and can be more effective in finding creative solutions, by:

- expanding the options for intervention;

- investing a diversity of people with incentives toward resolutions rather than disputes;

- uncovering the underlying interests of parties to a transaction or dispute; and

- being more transparent and communicative about goals and methods. ${ }^{48}$

The classic literature on the use (and non-use) of contracts in business settings offers a concrete illustration of how the traditional interactions of lawyers and clients mutually reinforce legal separation, and thus indirectly discourage development of PPL methods. When busi-

resolution of disputes through Alternative Dispute Resolution methods ("what are we going to do now about this?"). Rarely, however, is the "future tense" preventive mode considered. The preventive mode stresses design, systems analysis, collaboration, channels of communication, and compliance regimes ("what interventions could keep this risk from erupting into injuries or legal liability?"). Id. at 389-400.

46. Dauer, supra note 39 , at 93,95 .

47. For an overview of the elements of preventive thinking, see BARTON, supra note 2 , at $118-24$.

48. Id. at 121-24. 
nesses face risks based on an uncertain future, one option is to create an artificial certainty: they can create private contracts to construct what they hope will be an unshakable legal future. ${ }^{49}$ Significant resources are expended to design a legally enforceable world based on the promises that the parties exchange. Theoretically, contracts monetize uncertainty risks through legal rights and duties-regardless of what may be unfolding in the uncontrollable real world. Yet the seminal work of Stewart Macaulay, ${ }^{50}$ recently replicated by Iva Bozovic and Gillian Hadfield, ${ }^{51}$ reveal that business executives often prefer to resolve contract breaches through informal norms within the commercial community rather than to enforce those rights through litigation. ${ }^{52}$

49. Sep Nari Lee \& Thomas D. Barton, Promoling Comlrart Floxililily Through Trademarks? "Bronded" Inlelleclual Properly Licensing Practices, 2 LaPi.AND L. Rkv. 247, 248-49 (2014)

At least in part, people demand inflexibility in contracts because they want to control the future. This impulse may sound obsessive, but it is actually sensible. A perceived need for "future control" is best understood if we imagine a world without legally enforceable contracts. Exchange would proceed only where the performances of both parties are immediate- a synchronous transaction as in retail sales or bartering-or where one party is trusted to delay performance to some future moment. Absent that trust or some other non-contractual leverage like taking property as security against performance, the exchange will be too risky to undertake. Further, the greater the turbulence of background market or personal considerations, the harder it is to trust the other person. The greater the fluctuation of environmental conditions, in other words, the higher the risk of trusting that future performances will actually be made. A stable future reduces risk, heightens trust, and enables more transactions. If the reality of the future cannot be fully predicted or controlled, then creating a future artificially through contracts will supply that needed stability. $\cdots$

"Flexibility" is not valued in such a conceptualization. Flexibility seems inconsistent, at least on the surface, with capturing the efficiencies that flow from ensuring future performances-from "controlling the future." If a contract could reliably specify what shall be, then what really is when the time for performance arrives is irrelevant. Contracts are designed to define logally what future conditions shall obtain, and the parties should behave accordingly. "Flexibility" may seem to undermine that valuable legal suspension from reality.

Id. And yet, even as business managers continue to use highly future-specifying contracts, nearly ninety percent of the members of the broad-based membership of the International Association for Contract and Commercial Management ("IACCM") report that "flexibility and greater agility" is important for their contracts. Sluck in a Negotialion Rul, Commitment Mirters (Sept. 21, 2011), http://contract-matters.com/2011/09/21/stuckin-a-negotiation-rut/.

50. Stewart Macaulay, Non-rontrartual Relations in Business: A Preliminary Study, 28 Am. Soc. Rev. 55 (1963), and replicated by him since the original investigations. See Stewart Macaulay, Frepdom from Contract: Solutions in Search of a Problem?, 2004 WIs. L. Rev. 777, 778-83 (2004); Stewart Macaulay, The Real and the Paper Deal: Empirical Piclures of Relationships, Complexily, and the Urge for Transparent Simple Rules, 66 Mod. L. Ruv. 44, $46-47$ (2003). Sep also Ian R. MacNell, The. New Social. Contract (1980).

51. Iva Bozovic \& Gillian K. Hadfield, Scaffolding: Using Formal Contracts to Build Informal Relations in Support of Innovation (Feb. 25, 2015) (unpublished manuscript) (on file with University of Southern California).

52. Bozovic and Hadfield reinforce Macaulay's findings, but note important differences where contracts were made in contexts that business people self-reported as "innovative." $I d$. Contracts in innovative settings drew far more planning and periodic review during implementation. Even so, the parties were no more willing to use formal litigation 
Where this behavior pattern prevails, business people can easily slip functionally into using their lawyers like independent insurance agents rather than as professionals capable of offering strategic or practical advice. If clients abdicate from participation in contract design by just "turning it over to the lawyers," business managers are basically telling the lawyers to procure the best possible insurance against risks. The role of the law and lawyers is thereby reduced to the equivalent of an insurance transaction cost. Managers accept the transaction costs of obtaining a document that they hope will be used only as a last resort against significant losses. Separating contract design from the planning of the economic exchange and the cultivation of underlying commercial and personal relationships foregoes the kind of information exchange that could transform law into offering positive value or aiding in strategic planning. PPL, by contrast, seeks to expand the functional value of the law in contract formation, drafting, and implementation, by encouraging stronger and broader participation among lawyers, contracting parties, and those entrusted with implementing the agreements. ${ }^{53}$

In the odd paradox of the traditional pattern, the legal system is actually reinforced for limiting itself to an insurance value. The contract will justify the legal costs associated with its creation not by designing the law or lawyers to contribute to the underlying deal or the personal relationships of the parties, but instead by demonstrating that if needed, its drafted terms absolutely will be observed (or if not, compensation will be paid by the other side to cover the loss, just as in a formal insurance contract). The design incentives, therefore, favor prevailing in a legal conflict rather than furthering the underlying economic exchange or personal relationships-because in essence that is what the client is paying for. What the law is expected to deliver, in other words, is unshakable certainty or loss compensation. To succeed in that limited endeavor, business contracts will naturally become laden with legal vocabulary and clauses that have been previously verified within the legal container (i.e., interpreted authoritatively through litigation).

The lawyers therefore retreat to the legal container, making documents more and more self-referencing. The container elaborates its intellectual and professional separation because that is what is expected of it. But as a result, the document becomes yet more unreadable and the managers become less likely to engage substantively with the lawyers, even as their dependence on the lawyers and their container slowly increases.

The strong walls of the containerized legal system therefore persist, caught in a positive feedback loop that reinforces a division of labor between business and the law. The legal system ensures its rewards by

for enforcement. Id. For an in-depth empirical study and analysis of business litigation patterns, see Ross E. Cheit \& Jacob E. Gersen, When Businesses Sue Each Other: An Empirical Study of State Courl Litigation, 25 LAW \& SOC. INQUIRY 789 (2000).

53. Thomas D. Barton, Gerlinde Berger-Walliser \& Helena Haapio, Visualization: Seeing Contracts for Whal They Are, and What They Could Become, 19 J.L. Bus. \& ETHICs 47 (2013). 
perpetuating its own inaccessibility. But because the law does not contribute as fully as it might in adding economic value to business operations-i.e., because it plays the insurance role too strongly-the law is in danger of being cast aside if business people can find more efficient substitutes. We may see growth in the use of non-legal substitutes that depart from the traditional "fixed future" strategy for dealing with uncertainty. Businesses may instead rely overtly on the flexible coping mechanisms that Macaulay, Bozovic, and Hadfield suggest are already frequently used: reliance on markets or moral norms of reciprocity and the strength of long-standing commercial relationships. ${ }^{54}$ The growth of commercial arbitration clauses-with their less rule-based methods and outcomes-may be a way-station for even more flexible approaches to exchange disruptions. ${ }^{55}$

\section{B. Layer Two: Legal Systems and the Problems That Shape Their Evolution}

Until now, the separationist legal container has persisted because it has seemed to serve both the legal and business communities. And indeed, it may be efficient as well as appropriate for some purposes. The shape of the legal container arguably evolved to optimize resolution of certain sorts of problems, in particular ways-needs and methods that paired well in the historical period of nation building and industrialization, together with then-current information technologies associated with the printed word. ${ }^{56}$ This historical legal system deals especially well with boundary disputes, accidents, criminality, and breach of simple purchase and sale or borrowing agreements-issues of agrarian and early industrial economies that would have been commonplace during the evolution of legal rules, procedures, and professionals over the past 300 years. ${ }^{57}$ Such problems are largely resolvable through binary outcomes, coupled with money transfers. Particular land, for example, is either owned by one person, or another; a person is either at fault, or not, for injury to another; is either guilty of a crime, or not; a cow has been legitimately transferred or must instead be replevied to its

54. For a discussion of non-legal substitutes for the common law in resolving problems, see Barton, supra note 14. For a discussion of how legal solutions can be reinforced by harnessing human emotions and relationships, see Thomas D. Barton, Therapeutic Jurispmudence, Preventive Law, and Creative Problem Solving: An Essay on Hamessing Emotion and Human Connectiom, 5 Psychol. Pub. Pol'y \& L. 921 (1999).

55. A helpful introduction to commercial arbitration, especially as it affects international commerce and litigation, can be found in Thomas E. Carbonneau, Cases and

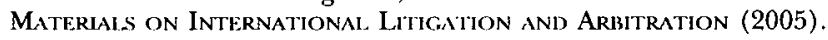

56. Katsit, ElEGikONiC MEDia, supra note 7, at 9 ("The introduction of new forms of communication that possess different qualities will not simply extend trends that are associated with print. The electronic media are not to be considered merely as more powerful versions of print. They have different mechanisms for transmitting and processing information, some of which will pressure the law to change course and become a different and not simply a more efficient institution."); $i d$. at 101 ("Law, like science, reflects certain assumptions that have been encouraged by the nature of printed information. Law has its own editorial process that filters out certain information in order to make the process operate efficiently.").

57. Thomas D. Barton, Justiciability: A Theory of Judicial Problem-Solving, 24 B.C. L. REv. 505 (1983). 
original owner. It is no coincidence that common law procedures are structured to provide judgments and remedies in that binary and money-damages format: the procedures are well-suited and efficient for resolving these structurally simple problems. ${ }^{58}$ Once the procedures have been invented, they become reinforced through professional norms that ensure the integrity (and perhaps use) of those very procedures.

However, that same optimized system may not be flexible enough to adapt successfully when the environment begins to make significantly different demands on it-when problems begin to change shape and when the optimized procedures are no longer as culturally acceptable. As J.B. Ruhl might label it, ${ }^{59}$ the legal system has to date evolved a significant "engineering resilience," which is "the capacity to maintain a high level of consistency of behavioral structure in the face of a dynamic environment of change. " 60 Yet the changes brought by Information Age technologies may be overwhelming that resistance. What the legal system may now need is an "adaptive resilience" that will permit greater flexibility in the face of the challenges. ${ }^{61}$ It is as though the

58. Id. Speaking generally, procedures for addressing problems are more strongly within human control than the problems that procedures seek to resolve. Hence humans try to design procedures that respond to the shapes of recurring problems. Flipping a coin, for example, is a marvelously cheap and accessible procedure, adapted to resolving binary problems without moral content: which team kicks off and which will receive. Democratic election is a binary procedure incorporating strong participation, debate, and legitimacy-more expensive, but worth the expense for the problem of choosing representatives in a republic. We tend not to reflect on the relationship between human problems and the procedures that have evolved to cope with them, so long as the procedure is well designed. But as legal philosopher Lon L. Fuller long ago observed, when the demands of the problem begin to outstrip the capabilities of the procedures that humans have invented to address those problems, we tend to turn toward tyranny or power as crude default problem solvers. Lon L. Fuller, Irrigation and Tyranny, 7 STAN. L. REv. 1021 (1965). Systems may evolve highly elaborate mechanisms to optimize its effectiveness in dealing with problems of a certain shape or structure. That may go far to explaining the shape of legal procedures, and the larger container in which they operate. Problems are "framed"-understood and processed-within the underlying beliefs and norms of the surrounding culture and philosophical values. Hence the legal system devises procedures for addressing risk by creating rules that reduce uncertainty through the creation of legally enforceable rights and duties. To interpret those rights and duties purely and consistently, however, legal procedures should proceed with as much detached objectivity as possible, analogously to the scientific method that co-evolved with the separationist legal systems. The co-volution and points of departure between the scientific method and legal thinking are described in Barton, supra note 23.

59. J.B. Ruhl, General Design Principles for Resilience and Adaplive Capacity in Legal Systems-with Applications to Climate Change Adaplation, 89 N.C. L. REv. 1373 (2011).

60. Id. at 1376.

61. Ruhl explains the difference between the two forms of system reliance:

Engineering resilience, which favors recovery as the design goal, and ecological resilience, which favors resistance as the design goal, thus are alike in that both concepts envision a system that has been pushed off of its equilibrium state by a disturbance. They differ, however, in terms of the mechanisms and strategies the system uses to avoid being pushed so far as to be functionally restructured. The engineering resilience strategy is to devote all system resources to staying near the equilibrium, the goal being to snap back. By contrast, the ecological resilience strategy accommodates the possibility of fluctuating within a basin of 
legal system has been built of non-flexing steel, full of power to withstand strong winds of change. But at some point, the better design may be for the structure to flex with the shaking of the environment.

This Article raises the possibility that the Information Age may be whipping gale force impacts on our legal structures, generating problems of such complexity, speed, scale, and required particularity of solution that our Industrial-era separationist legal containers can no longer cope effectively. As will be illustrated in Part II below, such stronger problem demands may arise both within business transactions and public regulation. Environments and their interplay of variables may be becoming more complex and volatile. The historic methods of the law and court-based rule enforcement may not be either fast enough in processing, or nuanced enough in the structure of its solutions to deal effectively with those more difficult problems. Over the long term, if the law cannot change its containerized procedures-like opening itself to pair with market and social norm approaches that can reinforce legal methods-then the law may ultimately find itself consigned to less economic and cultural significance. ${ }^{62}$

Writing in the context of design and regulation of the Internet, ${ }^{63}$ Lawrence Lessig has developed a typology that can be extended by analogy to highlight these growing vulnerabilities of our separationist legal system. Lessig distinguishes "smart" communications systems from "simple" ones, using the dial-up telephone to exemplify a smart system $^{64}$ and the Internet to show a simple one. A smart system is highly engineered by experts and is internally complex. Its functioning is fully understood by its designers and others who are well trained, but is not to be tampered with by amateurs. Users of the system play only a passive role-they may initiate the operation of the system, but cannot contribute to its development or even employ it in flexible ways. This loss of flexibility is an acceptable trade-off in the design of a smart system, however, because it is optimized to do particular, specific tasks very reliably and efficiently. So long as the tasks remain static, a smart system is sensible. When the demands on a system change, however-and especially when those demands come quickly, ${ }^{65}$ unpredictably, and dynami-

attraction to equilibrium, with the goal of avoiding "flips" from one structural state to another.

Ild. at 1377 (citations omitted).

62. Barton, supra note 14 .

63. Lawrience Lessis, The Future or Ideas 26-39 (2001). See also the discussion of Lessig's metaphor in Thomas D. Barton, Colluborative Conlrating as Preventive/Prosctive Law, in Proactive Law in a Business Environment, supra note 2, at 107, 117-22.

64. The talented folks at Bell Laboratories built thousands of miles of interconnected wiring, complex switching stations, and microwave towers, constituting the system beyond the handheld device in virtually every consumers' household. The role of the user was limited to simply dialing a desired phone number. Any other role for the user was likely to impede its operations. For a fascinating history of the development of telecommunications technology (and much else, including semiconductors and artificial intelligence) within Bell Labs, see Jon Geriner, The Idea Factory: Bell LabS and THE Great Age of American InNovation (2012).

65. See Katsh, Electronic Media, supra note 7, at 41-42 ("When society and the public have accepted an accelerated pace of change, is it possible for the law to maintain 
cally-the smart system starts to show its weaknesses. It cannot cope: it lacks the internal operating flexibility to meet different demands, and also lacks the diversity of inputs from users that might have enabled its ongoing re-design. The smart system thus always risks obsolescence or gradual degradation.

In contrast, says Lessig, are "simple" systems, characterized by the Internet. ${ }^{66}$ A simple system is designed to broaden participation and creativity in its use, like a bridge that connects unknown users for countless unexpected uses. As Lessig explains, the Internet is an "endto-end" or "E2E" simple network. 67 Virtually anyone can employ its protocols-assisted by "apps" to make communication and innovation yet easier-for whatever purposes he or she chooses. The system does not screen or prioritize its applications or communications. ${ }^{68}$ The explosion of creativity, innovation, and productivity gains through Internet communications could never have been envisioned by its creators: the simplicity of the system enabled its strongly diversified, unfiltered contributions. ${ }^{69}$

Our evolved legal system container exhibits all of the qualities of a "smart" system-qualities which constitute both its strength and the vulnerabilities that it is starting to face. Both its substantive content and its procedures are constructed by experts, and largely operated by them as well. Its rules are difficult to modify (though the genius of common law stare decisis is its ability to permit ongoing judicial adaptation of its rules to changing social norms). ${ }^{70}$ Its procedures for decision-making are hierarchical, highly formal, and strongly regulated. These qualities heighten the reliability of outcomes across courtrooms and reduce bias or corruption - thus optimizing operations within a limited framework, which is the raison d'etre of building a system "smartly." Nonetheless, non-experts are largely shut out from real participation. ${ }^{71}$ Even in pri-

old ways? If it is not capable of retarding change, or if more rapid change is desired by the public, will old mechanisms be discarded and will new ones be developed? An examination of the impact of the new media on the concept of precedent suggests that what has been developed over the past few centuries will need reworking and that the end result will be a system of law that is more accepting of change and more accepting of instability and uncertainty within the legal process. It will be more up to date but less of a force for preserving continuity with the past.").

66. LEssig, supra note 63 , at 3439 .

67. Id. at 34 .

68. Id. at 35 .

69. The idea of a "simple" decentralized system recalls the economic theories of Friedrich A. Hayek in his classic The Road to Serfdom (1944), in which Hayek challenges the capability of centralized planning to cope with issues that are dynamic, diverse, and complex.

70. See Katsh, Electronic Media, supra note 7, at 35 ("[T] he technology of print ... supplied one of the means through which the law has worked to balance stability and change. This method is the modern concept of precedent, one of the cornerstones of our system of law."). See id. at 40 ("Through its effect on the concept of precedent, print has contributed to public expectations that law can be used to achieve progress and that revolutionary change is unnecessary and inappropriate.").

71. Such a smart design was not necessarily consciously chosen-lawyers everywhere can be frustrated by its insularity. In addition to the frustrations of business lawyers who seek ways to connect more strongly to their clients, lawyers sincerely bemoan the lack 
vate contracting, where the law strives to be more of a framework for flexible use and to respond to the trade customs of merchant communities, the rules are complex and the products themselves can become unintelligible to untrained persons. As described above, users are shaped into abdicating in favor of the lawyers, which creates a positive feedback loop for yet further strengthening of the container walls.

Many questions arise from thinking about the law through Lessig's analysis of communications systems. Does the "smartness" of the legal container represent opportunity costs? That is, could the legal system be delivering greater value to the business and broader social communities at lesser costs, if it were made "simpler"? And if so, how could that be accomplished? Can its walls be made more permeable? As a system comprised of rules, institutions, and professionals, can it communicate better, build stronger loyalties between users and legal professionals, and stimulate legal innovation through stimulating user participation? Indeed, must it do so? Is the changing environment pressing in so hard as to threaten the structural integrity of the legal walls? And if so, how might the legal system best respond? Part III addresses these questions.

\section{Re-Designing the Legal Container for the Information Age}

Each layer of sheathing comprising the walls of the legal container-its language, procedures, and professional norms-could be separately analyzed, and each has been the subject of reform efforts. The inaccessibility of its language and documents, for example, has recently drawn much helpful attention in the movement toward legal "visualization"72 and the "Legal Design Jams" organized by Stefania Passera, Helena Haapio, Margaret Hagan, and Yana Welinder. ${ }^{73}$ Traditional procedures have also been under tremendous scrutiny, with their delays and high expense prompting Alternative Dispute Resolution ("ADR") innovations.74 Finally, regarding professional norms, thought-

of access to legal services by poor and middle class populations and work to extend legal expertise to them. While corporate counsel confront professional responsibility hurdles in expranding their role with business clients, attorneys serving clients of limited incomes face the opposite problem. Efforts to make legal services more affordable by "unbundling" legal services-having attorneys play only a limited role in representing clients by hiving off to the client tasks of fact development or form completion, for example-also encounter professional responsibility obstacles. For a helpful overview of the idea and ethical considerations surrounding unbundled legal services, see Stevens, supra note 38.

72. For a literature review of reform efforts toward "visualization" of the law and discussion of advances in Legal Design, see Gerlinde Berger-Walliser, Thomas D. Barton \& Helena Haapio, Irom Visual Law to Legal Design: Images as a Collaboralive and Creative Process, 53 AM. Bus. L.J. (forthcoming 2016).

73. See Margaret Hagan, Legal Design Jnm: A Skelchnole, Open LAW LA3 (Oct. 26, 2013), http://www.openlawlab.com/2013/10/26/legal-design-jam-sketchnote/.

74. Sep, e.g., Cakrik J. Menkill-Meadow el a.., Displte Risollution: Beyond titf Advirsarial. MODEI 3-58 (2005) (describing the philosophy and history of recent development of Alternative Dispute Resolution). Going further afield geographically and historically,

While we revere the "supremacy of law," other societies, with different needs and characteristics, promoted dispute settlement through nonlegal means. This was true in most oral cultures and even in most societies in which writing existed. 
ful attorneys have worked toward building stronger lawyer-client connections and value in a variety of contexts, e.g., transactions and contract formation; ${ }^{75}$ compliance with regulations; ${ }^{76}$ and in that most difficult circumstance for in-house counsel, internal investigations implicating corporate officers or directors. ${ }^{77}$

Part III seeks to extend such studies by examining the effects of the Information Age, with its technologies associated with digitalization and its globalization effects through virtually unlimited, cost-free distribution. Beyond finding ways to make the container walls more permeable, therefore, Part III considers how the Information Age may be dissolving its walls altogether-and the traditional containers of its ruleseven as it simultaneously generates new problems that outstrip the

What we label "alternative dispute resolution" was once supreme, while the law, which we consider supreme, would have been treated as an alternative.

Katsh, Electronic Media, supra note 7, at 52.

75. See, e.g., George J. Siedel \& Helena Haapio, Using Proactive Law for Competitive Advantage, 47 Am. Bus. L.J. 641 (2010); George G. Triantis, Improving Contract Quality: Modularily, Technology and Innovalion in Comiract Design, 18 STan. J.L. Bus. \& FIN. 177 (2013).

76. For helpful, practical suggestions toward constructing a regulatory compliance framework through management systems, see Richard S. Gruner, General Counsel in an Era of Compliance Programs and Corporale Self-Policing, 46 Emory L.J. 1113 (1997). He writes,

Previously, most general counsel were primarily crisis-driven legal counselors, well versed in the business activities and legal environments of their corporate clients and easily accessible to corporate executives as specific legal issues or crises arose. However, with the advent of new self-policing efforts by corporate organizations-spurred by rising public expectations, new legal rewards for selfpolicing efforts, and rapidly increasing liabilities at stake - general counsel have assumed new leadership roles in shaping corporate law compliance systems.

As they assume these leadership roles, general counsel and many of the corporate counsel which they oversee are increasingly resembling specialized corporate managers focusing on the systematic practices their companies use to ensure law compliance. Indeed, this article will argue that much of the work performed by general counsel to promote corporate self-policing can best be understood by evaluating general counsel as specialized corporate managers rather than as mere legal advisors.

Id. at 1114 .

77. Alan L. Silverstein, Ethical Issues Facing Corporale Counseh 13 ANTITRUst 18 (1998). The internal investigation dilemma has prompted Alan L. Silverstein to describe a structure of a corporate law department that could also help build better everyday connections in both transactions and compliance. Silverstein distinguishes two distinct sorts of lawyers within a company: first the "business unit" lawyer "who [is] assigned to a particular corporate business unit or division to provide continuing legal advice on a wide array of issues. The employees who regularly deal with such attorneys may tend to view them as 'their' attorncys." Id. at 18. In contrast are the "corporate counsel" lawyers,

who tend to be employed in the "headquarters" of the legal department to advise all the corporation's entities on a particular subject matter, such as antitrust. In those legal departments that have both types of corporate counsel, business unit counsel typically have the primary relationship with the businesspeople, and refer questions to the appropriate subject-matter counsel when the particular subject arises.

Id. This bifurcation suggests that the "business unit" attorney could maintain a stronger PPL style, with the Corporate Counsel retaining traditional stronger independence. In an internal investigation, "bringing a subject-matter counsel into the discussion, whether in a routine counseling situation or an internal investigation, may help emphasize to the employee that counsel represents the corporation." Id. at 19-20. 
capabilities of traditional legal methods. The result is a call to extend PPL and, ultimately, to re-design our ideas about the historic separatist Rule of Law.

\section{A. Dissolving the Walls of the Legal System and Rules}

Throughout the Enlightenment era and still today, judicial decisions and legislation are contained within the printed word-a format that imbues the law with heightened authority. ${ }^{78}$ The prescient Ethan Katsh described more than twenty years ago how the arrival of the printing press in the 16 th Century moved the law into printed media, with profound effects on the Common Law. ${ }^{79}$ Katsh then foretold how the modern displacement of the printed word by electronic information delivery methods could similarly change the foundations of legal structures and thinking. ${ }^{80}$

Extending our metaphor of the legal container to that of its products-i.e., the legal rules themselves-what if we were to imagine legal rules as information ${ }^{81}$ that is delivered to the population inside containers or packages, just as consumer goods are delivered inside packages? What would these containers look like? Would they be similar to

78. Kitsie, Electronic: Midid, supra note 7, at 83-86. Sep Katsif, Digital. World, sufma note 7 , at 8 ("Printing was the first mass medium and the first medium to enable large quantities of uniform, reliable, and authoritative information to be distributed widely.").

79. Sep Katsh, Eifctronic MfDia, sufwr note 7, at 87 ("The embodiment of law in printed form did not simply replace law in [handwritten] form. Rather, it replaced a system of dispute resolution that had often involved written law and oral tradition working together. Printed law, therefore, emphasized decision making according to rules more than some previous systems because attention was focused on rules in a way that had not occurred earlier. In this respect, it is important to recognize that print also brought about a narrowing of the judge's focus. Judges in earlier periods had been able at times to escape rule-oriented decisions because their attention was not bound to a printed or even a written text. They had options that were not available to later generations of judges whose decisions had to be made 'by the book." ).

80. Sep KATsh, Dicrial. WORI,1), supru note 7, at 16 ("Law is not merely a force that is used to exercise authority over others. It is, at the same time, an institution and a process that is affected by the very media it is attempting to regulate. The new media, in other words, change law at the same time that law is used to regulate the use of the new media since the two forces relate to each other in a dynamic and interactive manner."). law:

81. Katsh describes the crucial role of information as a structural element of the

Law can be looked at in many ways, but in every incarnation, information is a central component. As one lawyer recently wrote, "from the moment we lawyers enter our offices, until we turn off the lights at night, we deal with information." Information is the fundamental building block that is present and is the focus of attention at almost every stage of the legal process. Legal doctrine, for example in information that is stored, organized, processed, and transmitted. Legal judgments are actions that involve obtaining information, evaluating it, storing it, and communicating it. Lawyers have expertise in and have control over a body of legal information. . . Indeed, one way of understanding the legal process is to view information as being at its core and to see much of the work of participants as involving communication. In this process, information is always moving-from client to lawyer, from lawyer to jury, from judge to the public, from the public to the government, and so on.

Id. at 7 . 
the packaging and methods used in Industrial-style distributions? And does such packaging contain assumptions about people and social control? Indulging this metaphor in the paragraphs below will help to reveal potential impacts of digitalization and globalization on the legal system. ${ }^{82}$

Just like the packaging of many commodities that are mass-produced and distributed from a central source in an industrial economy, legal rules could be seen as sets of words packaged at a central source (like a high court or legislature) so as to be:

- sturdy (i.e., stable and permanent);

- rigid and sealed (so as to prevent tampering-i.e., to produce validity in result when interpreted or adjudicated);

- "stackable" (i.e., standardized in shape or organization for easy transport geographically, so as to produce reliability of result across courtrooms); and

- labeled to identify what is inside, complete with warnings about misuse (so as to meet Due Process requirements of notice and fair warning about the liability or punishment for "misuse" or for breaking the rules).

In designing its rule containers in this way, the law mimics huband-spoke Industrial production and distribution methods, as well as Enlightenment values. The ideas inside the packaging are expertly designed by judges and legislators and hierarchically distributed downward-part of the "smart" system not to be tampered with by users, as explored in Part I. To achieve consistency, they are also relatively inflexible. They can be used only as directed, thus largely channeling control and creativity into expert lawmakers and lawyers rather than in citizen users-extending the pattern identified in Part I regarding lawyer-client interactions surrounding commercial contracting. The packages give formal warnings and instructions for use, but are sometimes made unreadable by their complexity and verbosity. Hence, consumers sometimes do not know what they are buying; they have to rely on intermediaries (i.e., lawyers) for help. But the labels do at least identify the category of what is inside-serving a signaling function for consumers to be aware of the product's existence.

Such legal packaging is also consistent with older information technology, structuring how knowledge is gathered, collated, classified, assessed, and shared. ${ }^{83}$ Throughout the Enlightenment and Industrial era, information was largely collected centrally and then distributed or transmitted from those central sources. Scientists and philosophers col-

82. MCLuHAN, supra note 22, at 174 ("A new medium is never an addition to an old one, nor does it leave the old one in peace. It never ceases to oppress the old media until it finds new shapes and positions for them.").

83. For a fascinating history of the mutually entwined growth of modern law and the printed word, see KaTSH, Digital World, supra note 7, at 1-101. See also the eloquent article by Richard K. Sherwin, Visual Jurisprudence, 57 N.Y.L. ScH. L. REv. 11 (2013) (analyzing emerging visual media). As Sherwin says, "The proliferation of electronic visual media has transformed social and cultural practices of meaning making around the world." Id. at 14. 
lected and bundled information according to categories that made sense to them. ${ }^{84}$ Their books-and eventually radio and television broadcasts-were then distributed hierarchically to readers, listeners, or users. ${ }^{85}$ The packages came to those users in an unchangeable format, arranged according to what made sense to the persons who collected, compiled, and classified the information.

Individual differences or preferences among the users really could not be taken into account, which once again reflects Industrial Age distribution and marketing. The information was contained in tight ways and distributed in standardized formats to users who were forced to be homogeneous in their demands. As to the vision of people and relationships, each person was individually responsible for how the products were used-reflecting Enlightenment expectations that people are capable of detached, rational individual choice about these laws-and then held accountable for those choices.

These limited and hierarchical Industrial and Enlightenment patterns of information collection, combination, transfer, and sharing are fast being displaced by the binary coding of information ("digitization") that can be processed by computers and transmitted over the Internet. Digitization has rendered many traditional containers superfluous. The sounds and words of musical songs, for example, have been reduced to information that is perfectly replicable. And once the Internet was invented, this information could be transferred globally-instantly and virtually cost-free. The container of the song-be it on vinyl, cassette, $\mathrm{CD}$, or DVD-was no longer important. Containers were simply not needed, at least to transmit the song; indeed, its packaging became clumsy and inefficient. ${ }^{86}$

Freeing information from containers may eventually affect how people think. ${ }^{87}$ It may make people more integrative, and less linear, in their thought process. ${ }^{88}$ It may make people see patterns more easily. And it almost certainly will prompt people to use graphic images far

84. KATSH, DIGTAL, WORID, sufra note 7 , at 101.

85. McLuhAN, supra note 22, at 172 ("The typographic extension of man brought in nationalism, industrialism, mass markets, and universal literacy and education.").

86. Indeed, as digitalization proceeds, tangible goods themselves can be similarly reduced to pure information in binary formats that can be transmitted without any traditional container. A receiver of the information can re-generate a container, if desired, through a $3 \mathrm{D}$ printer. The same is just now becoming true regarding human tissue and human organs. Organic material can be digitalized into pure information and transmitted globally. Using stem cells, a new container for the information can be generated through a "bio-printer." ORGANOvo, http://www.organovo.com/tissues-services (last visited May 5, 2015).

87. See. Christina Spiesel, More. Than a Thomasand Words in Response to Rebecca Tushnel, 125 Hakv. L. Rev. F. 40, 41 (2012) (distinguishing pictures from words, with pictures "always associational," acquiring meaning from our associations with them rather than simply their grammatical order).

88. See Katsh, Electronic Media, supra note 7, at 257-59 (describing the analytical thinking traditionally stressed in legal education); see also MCLuHAN, supra note 22, at 15562 (contrasting the simultaneity of electronic media versus linearity and fragmentation of print media). 
more, and words less, ${ }^{89}$ with implications for heightened emotionality. ${ }^{90}$ That is how computer information is packaged, and people process that information differently. ${ }^{91}$

But even before that evolution of the thinking process, attitudes will shift about how information should be created and shared, especially with the arrival of the Internet. People will expect that information is immediately and digitally available for them to search as they choose; that they should be able to understand and participate actively with the information, perhaps modifying or adding to it; and that it should be readily shareable. ${ }^{92}$ As Richard Susskind writes,

If you were a user of the Web in 1997 . . you would have been the passive recipient of whatever information website providers chose to publish or broadcast in your direction. Today, users are becoming providers. Readers are authors. Recipients are now participants. Users can contribute. We are finding radically new ways to produce information and to collaborate with one another, whether as bloggers, users of social networks, or contributors to shared, online resources such as Wikipedia and YouTube. ${ }^{93}$

89. Elizabeth G. Porter, Taking Images Seriously, 114 Colum. L. Rev. 1687 (2014); Richard K. Sherwin, Neil Feigenson \& Christina Spiesel, Law in the Digilal Age: How Visual Communication Technologies Are Transforming the Practice, Theory, and Teaching of Law, 12 B.U. J. Scr. \& TECH. L. 227, 230 (2006); Tobias Mahler, A Craphical Interface for Legal Texis?, in Nordic Yearbook of LAW and Informatics 2010-2012: The Internationalisation of Law in the Digital Information Society 311 (Dan Jerker B. Svantesson \& Stanley Greenstein eds., 2012); Collette R. Braunschwig, Law Is Nol or Must Not Be Just Verbal and Visual in the 21sl Ceniury: Toward Mullisensory Law, in NORDAC YEARBOOK OF LAW AND Informatics 2010-2012: The InTernationalisation of LaW in the Digital Information SOCIETY, supra note 89, at 231.

90. "A visual image has the power to access virtually every human emotion with extraordinary efficiency. Foreboding, horror, tenderness, mirth - a visual image can elicit any of these in less time than it takes to read this sentence." Nancy Illman Meyers, Painting the Law, 14 CARdozo ARTS \& ENT. L.J. 397, 398 (1996). See also Sherwin, supra note 83, at 12-13 (" $[\mathrm{I}]$ ncreasingly, the search for fact-based justice inside the courtroom is becoming an offshoot of visual meaning making. But when law migrates to the screen it lives there as other images do, motivating belief and judgment on the basis of visual delight and unconscious fantasies and desires as well as actualities.").

91. Rebecca Tushnet, Worth a Thousand Words: The Images of Copyright, $125 \mathrm{HARV}$. L. Rev. 683, 690-91 (2012) ("Images are more vivid and engaging than mere words, decreasing our capacity to assess images critically because we are more involved in reacting to them. And, because we process images so quickly and generally, we may stop looking before we realize that critical thought should be applied to them. Pictures are perceived more as a gestalt, while texts appear to the reader in a set sequence, most or all of which needs to be processed for the whole to be understood.") (citations omitted). Cf. Lucille A. Jewell, Through a Glass Darkly: Using Brain Science and Visual Rhetoric to Gain a Professional Perspective on Visual Advocacy, 19 S. CAL. INTERDisc. L.J. 237 (2010) (stating that lawyers could be better advocates by harnessing how people cognitively process visual information).

92. See Katsh, Electronic Media, supra note 7, at 240 ("We are experiencing a quantitative explosion in the production of information that allows audiences to be reached instantaneously and simultaneously and increases opportunities for individuals to obtain information and organize it according to their needs. . . Their effects ... suggest that some concern for the current view the law takes of the individual is warranted.") (footnotes omitted).

93. Susskind, supra note 9 , at 12. 
Digitalized information as posted on the Internet is not "contained"-instead it is malleable, with contours shapeable by individual users; contingent, i.e., subject to constant revision; intellectually accessible, with a heavy use of graphic images accompanying the words; and freely available for use, not subject to hierarchy or guarded by experts. Here is how Sherwin, Feigenson, and Spiesel describe the change:

Digital technologies allow the pictures and words from which meanings are composed to be seamlessly modified and recombined in any fashion whatsoever, while the Internet allows practically anyone, anywhere, to disseminate meanings just about everywhere. The Enlightenment-era insistence upon essentialist foundations (whether exemplified by Locke's empiricism, Kant's rational categories, or other totalizing epistemologies) is being challenged by digital experience, which has helped to inspire an alternative model of knowledge and reality as a centerless and constantly morphing network of relations. ${ }^{44}$

The contrast with traditional legal rule containers is often stark. The inaccessibility of expert-created and expert-guarded legal rules, coupled with the high costs of summoning the system of interpreters. and power standing behind the ideas, may drive modern people toward non-legal alternatives. Extending Susskind's thoughts, people are now exposed to the strongest and broadest participation patterns in creating, using, and sharing. Increasingly in modern life, individuals are being empowered to make whatever social connections they choose, along whatever dimensions they can imagine, sharing a huge range of property and human functions. But not in the law, because the containers are too rigid, sealed, standardized, and intellectually inaccessible. That will almost inevitably change. As Katsh writes,

The change in the means of access to legal materials will ultimately affect how law is perceived by lawyers and by others who may have an interest in such materials. Print supported a standardized set of categories, and every case was placed into one or more categories. The internal organization of legal materials need no longer conform to such a system. Yet it is this system that, at least in part, unites lawyers by influencing how they think about law. As new techniques for finding electronic data replace the habits encouraged by print, the organization of data will begin to reflect individual users' varied views of law rather than some structure that was developed in order to use material in printed form. This new and less-standardized structure will not require that labels be placed on data or that there be any limit to how a user wishes to organize data. How a person perceives the body of data will depend more on what that person's needs are and less on what the needs of a publisher are.

If law cannot be expected to possess the same internal organization in the future, neither can it expect its external boundaries

94. Sherwin, Feigenson \& Spiesel, supra note 89 , at 230 (citations omitted). 
to remain as fixed as they are today. The question of what is law, which even today is often a matter of controversy, or the issue of who is entitled to dispense "legal" information will become even more difficult in the future. ${ }^{95}$

The law and its methods thus seem to be drifting away from popular cultural attitudes and expectations about information, knowledgecreation, hierarchy, and control by power. ${ }^{96}$ To retain its cultural stature as well as effectiveness, the legal system should consider opening itself up and the containers of its rules to stronger influences of the market, social norms, and environmental design-but to do so in thoughtful ways that respect historically underlying Western liberal values. Important new ideas are being proposed. David Orozco, for example, has described the possibilities (and disruptive potential) of "crowdsourcing" governmental legal norms; ${ }^{97}$ stronger uses of human relationships to supplement the use of formal power in enforcing legal norms have also been explored, ${ }^{98}$ as have ideas about webs of alliances to promote contracting flexibility under changing conditions ${ }^{99}$ and better organizational design to promote communication and generativity. ${ }^{100}$ The solutions point to greater connectedness, not to either authoritarianism or abdication. Ruhl and Katz, for example, hold a "deep skepticism that top-down, centralized regulation can avoid unintended consequences or keep up with co-evolving systems [;] . . more flexible, decentralized forms of governance fit better with the complexity model."101 Citing Barbara Cherry, Ruhl and Katz continue that,

rapid technological, social, and economic change-systems coevolving with law-demand a more adaptive governance structure ... . The answer to legal complexity, in other words, is not to hack away at the legal system and declare victory in the campaign for legal simplification; rather, the focus of these and other complexity theorists offering prescriptive advice is on building adaptability and resilience into legal systems . . . . [L]aw cannot deregulate its way there, nor can it command-and-control its way there. ${ }^{102}$

95. Katsh, Electronic Media, supra note 7, at 223.

96. Barton, supra note 14.

97. Orozco, supra note 10, at 12-14. See also Triantis, supra note 75 , at 202 for a peer production of contract design.

98. Barton, sutra note 54 .

99. Id. See also George Dent, Lawyers and Trust in Business Alliances, 58 Bus. Law. 45, 45 (2002) ("Strategic business alliances (including joint ventures, licensing, franchises, dealerships, distributorships, and strategic investments) are proliferating rapidly due to many economic forces, including economic globalization, intensifying competition and the resulting need of businesses to speed up technological innovation and to adjust faster to changing markets.") (footnote omitted).

100. See generally Nicholas Argyres \& Kyle J. Mayer, Conlract Design as a Firm Capability: An Integration of Leaming and Transaction Cost Perspectives, 32 ACAD. MGMT. Rev. 1060 (2007) (aligning contract terms with transaction attributes, and then matching contract design capabilities with particular organizational personnel).

101. J.B. Ruhl \& Daniel Martin Katz, Measuring, Monitoring, and Managing Legal Complexity, 101 Iowa L. Rev. 191, 209 (2015).

102. Id. (footnote omitted). 
Understanding mutually influencing connections and the importance of human relationships has always been central to PPL thinking and methods. Hence PPL may be positioned to flourish in the Information Age-and to offer a way to transition the legal system to emerging trends in business and society. It will require expanding its horizons yet further beyond the walls of the traditional legal system, looking for ways to link up with other problem-solving methods and to harness the very technologies that are creating the disruptions. But PPL's historic combination of pragmatism and systems-thinking bode well for its success.

\section{B. Engaging New Problems}

Digitalization and globalization are generating legal problems of greater complexity, ${ }^{103}$ speed, scale, and particularity-attributes that make resolving the problems more difficult. ${ }^{104}$ Compounding the difficulty are the volatile background conditions under which the problem arises, and its local fragmentation. Fluctuating or fragmented backgrounds are significantly more difficult to manage, as they may require monitoring and adjustment of solutions. ${ }^{105}$ Many examples could be cited, economically and socially, such as:

- the evolution of long, interconnected supply chains;

- coordination of outsourcing and offshoring capabilities;

- environmental concerns that magnify local actions into regional or even international concern;

- political instability and corruption concerns as goods pass through multiple national borders or require marketing licensure;

- mass movements of human populations through internal displacement or legal or illegal international immigration;

- unstable commodity and energy markets;

- differential trade restrictions and antitrust sensibilities;

- accelerating technological obsolescence cycles;

- product design that confronts thickets of patent licenses; and

- growing ease and profitability of product counterfeiting or intellectual property infringement.

Such problems would have challenged legal methods even at their peak; and yet those historic ways of coping with problems seem to be on the decline. Demand is growing among the business community and citizenry generally for non-hierarchical delivery of information, norms,

103. See Paul Lippe et al., Legal By Design: A New Parculigm for Handling Complexily in Banking Regulation und Elsewhere in Law, 93 OR. L. Rtv. 831, 834 (2015) ("[T] he exponential rise of legal complexity [] has unfolded over recent centuries. Complexity in law is in part a response to the increasing complexity of social interactions and economic exchanges in society.").

104. Fuller, supra note 58, at 1021-42 (suggesting how problems in general become more difficult as they become more complex; as the background conditions in which they arise are more unstable and as the problems affect a larger proportion of the public).

105. Id. 
and procedures, coupled with the need for flexible, particularized, ${ }^{106}$ and socially participatory solutions.

\section{PPL Methods Applied to Intellectual Piracy}

Intellectual property issues exemplify the sort of growing problem complexity that threatens to outstrip industrial-era legal methods. Francis Gurry, head of the World Intellectual Property Organization, worries generally about capabilities for resolving intellectual property problems:

The rapidity of development of the technological base challenges the capacity of the intellectual property system to adapt adequately and within a sufficiently short period of time to serve a useful function in respect of new developments. Given the speed of change, are we able to adapt rights that were designed for mechanical technology and the printed medium with sufficient swiftness? Does the time allowed for an effective response enable us to know enough about the new development and its future direction to adapt rights or to design new rights appropriately? ${ }^{107}$

We consider in detail below just one example that highlights both Information Age pressures on the legal system and the possibilities for harnessing its methods to achieve legal system reform: the piracy of goods and intellectual property. Even a cursory summary of its intricacy illustrates how law and business cannot remain fully distinct in understanding and addressing the problem. Resolutions must be based in an integration of law with market dynamics, social norms, and the architecture of environments and product design. ${ }^{108}$

As the piracy example unfolds, its complexity will also serve to illustrate the steps involved in the systemic-design-thinking of PPL: ${ }^{109}$

- Understand broadly the nature of the problem and why it persists. Explore all aspects of the problem-technical, financial,

106. Better information enables greater particularization of problem solving, as in the quest for personalized medicine based on particular genetic make-up. But on the other hand, "The rapid movement of information fosters group concerns and discourages acts that would stress individual differences." KATSH, ELECIRONIC MEDIA, supra note 7 , at 55 .

107. Francis Gurry, The Evolution of Technology and Markets and the Management of Intellectual Property Rights, 72 CHI.-KeNT L. Rev. 369, 378 (1996).

108. Some of the ideas presented below for addressing piracy of intellectual property are extracted from multiple published and conference presentation sources, and may not be specifically referenced. Some helpful resources include the following: Press Release, Int'l Trade Admin., Top 10 Ways to Protect Yourself from Counterfeiting and Piracy (Apr. 10, 2007), http://trade.gov/press/press_releases/2007/top10-stopfakes_041 007.pdf; Kevin M. Reichelt, Int'l Intellectual Prop. Inst, Avoiding Counterfeit GoOds: A How-To Guide fOR Consumers (2010), http://iipi.org/wp-content/uploads/ 2010/07/Identifying_Counterfeit_Goods_-_A_Guide_for_Consumers.pdf; INT'L TRADEMARK Ass' $N$, ADDRessing THE SALE OF COUNTERFEITS ON THE. INTERNET (2009), http://www inta.org/Advocacy/Documents/INTA\%20Best\%20Practices\%20for\%20Addressing\%20 the\%20Sale\%20of\%20Counterfeits\%20on\%20the\%20Internet.pdf; Eric R. Waltmire, How to Secure Your Client's Brand Against Counterfeiting Operations in Asia, 22 DCBA BRIEF 46 (2009).

109. BARTON, supra note 2 , at 52-53. 
geographic dispersion, frequency and nature of harms inflicted, and cultures in which the problem thrives or shrinks. Identify the elements of the problem, and how they combine. Look for "soft-spots" where interventions might be targeted to disrupt the conditions that produce the problem.

- Design as many different sorts of interventions, so as to disrupt as many connections as possible, realizing that some intervention methods are effective in some contexts, but not in others.

\section{The Piracy Example: Particulars}

In many ways, piracy is the archetypal Information Age legal problem. It has become far more significant as a result of the very technological breakthroughs that have made intellectual property rights both stronger and more valuable. ${ }^{110}$ Ironically, the more powerful the monopoly rights (and commensurate monopoly pricing potential) granted to patented goods and copyrighted expression through intellectual property laws, the greater the economic attraction for pirates. ${ }^{11}$ Hence piracy cannot be prevented or resolved simply by tightening legal rules; stronger rules will increase the incentives for pirates to flout the law. This suggests that piracy will be a chronic problem, rather than one that can succumb to a single application of a solution. The methods should therefore set up processes that are self-sustaining and selfadapting once begun, rather than single-point instances of law enforcement. Furthermore, even though the infringed rights are held privately, the global geographic reach of piracy and its tremendous volume means that it has become a public problem, attracting significant governmental enforcement efforts.

\section{Understanding Diverse Dimensions of the Problem}

The piracy-counterfeiting problem presents itself in diverse waysmeaning that a single sort of intervention or method is not likely to address all of the forms in which the problem presents itself. Here are some of the reasons, which again illustrate the heightened challenges for legal resolution:

- The technologies for copying vary (although all involve the ability to produce at a price that is lower than the monopoly pricing of the authentic goods) - some involve hard-goods manufacture, some digital copying.

- Copies have differing information costs associated with discovering that it is not authentic-sometimes prohibitively high, but sometimes virtually cost-free through simple visual inspection.

- The markets in which copied goods are bought and sold varysome are physical and local, some are virtual and global.

110. See Bryan A. Liang, A Dose of Reality: Promoting Access to Pharmeceuticals, 8 WAKE Forest INIELL. Prop. L.J. 301 (2008) (explaining how stronger intellectual property rights attracts stronger efforts at piracy).

111. Id. 
- The items copied vary greatly in value-some relatively low, some extremely high.

- The markets for illicit copies vary in their breadth, or how widespread the use is of the item. They can range from millions of users (like songs or some software) to relatively few (as with aircraft parts or some pharmaceuticals targeting rare conditions).

- The nature of the wrongdoers (illicit suppliers-producers) varies-it is sometimes organized crime or even terrorist organizations working on a world-wide basis, but sometimes young people sharing software or music with their friends.

- The attitudes of the consumers of pirated or counterfeited goods vary-sometimes they are innocent victims of fraud; sometimes they are fully aware they are buying a copy. Among this "fully aware" group, members sometimes want to hide that the item is a copy, but, at other times, are not concerned that people know it is a copy or that its use is inherently hidden.

- The problem readily crosses national boundaries. This challenges virtually all centralized solutions, especially legal solutions because of the limits of each country's sovereign reach and enforcement capabilities.

\section{Suggesting Procedures for Resolution}

This variability in piracy problem contexts suggests that the design of legal solutions must have sustainable, systemic methods incorporating incentives or ongoing commitments of resources: features that are ongoing, diverse in method, and decentralized. It should attempt multiple interventions: (1) reduce the supply of illicit copies, (2) reduce the demand for illicit copies, and (3) disrupt markets where supply and demand meet. Some of the ideas involve traditional legal rules and enforcement mechanisms; some harness market incentives; yet others involve technical fixes, product design, or social reinforcement. Confronting the problem successfully will require connecting the law with other methods for social control. By consciously designing such integration, rather than letting alternative methods jostle one another for prominence, the law will not only enhance its effectiveness but also better prevent unintended undermining of core Western liberal legal values.

\section{i. Reducing the Supply of Illicit Copies}

Here are a few suggested measures to reduce the supply of pirated goods or ideas, illustrating the close connectedness among dimensions of a problem and the particular blend of legal and non-legal procedures that may best address each dimension:

- If the items are produced by transnational criminal organizations, disruption or deterrence is best accomplished by tradi- 
tional law enforcement agencies, especially those that can cooperate on a national or international level. 112

- If the items are produced by individuals on a small scale, use attitude-social awareness campaigns. These are most efficiently carried out by national governments, ${ }^{113}$ but sometimes done by the producers of the products and industry associations.

- If the infringers are mid-level, and basically legitimate businesses-like businesses that copy, produce, and sell fashion designs - ensure that the laws adequately address the activity. In the fashion world, for example, intellectual property rights are ill-defined. ${ }^{1 / 4}$

- For all kinds of producers, make the items more technically difficult to copy. ${ }^{115}$ This reduces the profits from copying and creates barriers to entry from low-level opportunists. This could be done through conscious design changes or the use of a particular mixture of materials. Even where more elaborate designs would increase costs for rightful producers, the measures would nonetheless be worthwhile wherever those extra costs are recaptured through lesser IPR theft. It may also increase the quality of the authentic goods, which makes copies less attractive and forces sellers of illicit copies to lower their prices (and profits, which then ultimately shrinks their market).

- Some illicit copying occurs when manufacturers outsource production to subcontractors, supplying those contractors with the molds, dyes, or other production materials to produce authentic goods. Corrupt persons at the subcontractor shop can produce extra items, beyond the contracted-for requirements, and sell these illicit items on their own. ${ }^{16}$ Public agencies and law enforcement institutions, especially in some countries, may not be able to monitor this activity due to limited resources and cul-

112. See, e.g., UNODC Launches Consumer Awareness Brochure on Counlerfeiting and Organized Crime, U.N. OFF. ON DRugs \& Crime (June 5, 2014), http://www.unodc.org/ unodc/en/frontpage/2014/June/unodc-launches-consumer-awareness-brochure-oncounterfeiting-and-organized-crime.html.

113. See, e.g., Off. of Health, Safeir \& Sec., U.S. Dep't of Enfrgy, Suspect $/$ CounTERFEIT ITEMS AWARENess TRAINING (2007), http://energy.gov/sites/prod/files/2014/ 06/f16/SCI_Training_Manual.pdf.

114. Julie P. Tsai, Fashioning Protection: A Nole on the Prolection of Fashion Designs in the Uniled Siriles, 9 Lewis \& Clakk L. Rrv. 447, 451-61 (2005).

115. 5 Ways to Prevent Anti-Diversion and Counterfeiting of Products/Packaging, JoHNSBYRNE BLOG (Jan. 6, 2015), http://www.johnsbyrne.com/5-ways-prevent-anti-diversioncounterfeiting-productspackaging/ [hereinafter JoHnsBYRnE BLoc] ('Your product's fingerprint can be any number of things that will alert you to its legitimacy. Whether it is a sticker, a design feature, or some other technology that works for your product line, having something unique to your product can help you discover diverted and counterfeit products in the sales pipelines. Consider adding a design to your package such as a unique ink, coating, finishing effect, or material that is difficult to discover or be replicated. The harder it is to counterfeit your product, the less likely it can be sold without detection.").

116. See Renu Chopra, Outsourcing That Leads to Counterfeil Shoe Production, OuTsource BloG (Sept. 6, 2010), http://www.theoutsourceblog.com/2010/09/outsourcingthat-leads-to-counterfeit-shoe-production/. 
tural barriers. ${ }^{117}$ But analogously to independent auditors of financial accounts and records, private companies could set themselves up as local "production auditors" who are contractually empowered to reduce piracy by entering the premises of production subcontractors to monitor and track materials and inventory levels.

\section{ii. Possible Measures for Shrinking the Demand for Copied Items}

- As to items where the consumer is unaware that the item is copied and would not buy it if the buyer knew the truth, take steps to lower the information costs to the buyer (or enforcer) about the true nature of the product. Build in authentication measures that the buyer can easily use.

- One possibility is to place bar codes on many more items, and to have legitimate producers freely distribute smartphone apps that would enable the average individual to certify authenticity by holding his/her phone up to the item. ${ }^{118}$ In some contexts, like many pharmaceuticals or aircraft parts, counterfeiting poses such strong safety risks that buyers would have self-interested reasons to take the time to check authenticity. ${ }^{119}$

- For other sorts of goods, manufacturers could embed authenticating messages or marks using DNA markers, ${ }^{120}$ RFID tags, ${ }^{121}$ or invisible inks ${ }^{122}$ that can be detected only (but easily by Customs inspectors) with ultra-violet light. The markings could

117. See U.N. Off. on Drugs \& Crime, The Globalization of Crime: A Transnational Organized Crime Threat Assessment 173 (2010), https://www.unodc.org/documents/data-and-analysis/tocta/TOCTA_Report_2010_low_res.pdf.

118. See Pouwan Lei et al., A Secure Mobile Track and Trace System for Anti-Counterfeiting, INT'L Conf. E-TeCh., E-Com. \& E-Ser. 686-689 (2005).

119. This could even be accomplished through "embedded" technology:

Engineers can use multiple approaches to preventing counterfeit products from functioning in a system and thus prevent potential damage. At the simplest level, a product such as a battery or an ink cartridge can include an electronic signature that the host system must recognize for the product to work. To add an extra layer of security, the product can include an encrypted identifier to ensure that the counterfeiters cannot duplicate the signature.

David Richetto, Advanced Securily Prevents Counterfeil Products, EDN Network (Nov. 4, 2011), http://www.edn.com/design/consumer/4368557/Advanced-security-preventscounterfeit-product.

120. James A. Hayward, Using DNA to Prevent Counterfeiling and Product Diversion, TAPPI (Sept. 19, 2007), http://www.tappi.org/content/events/07place/papers/hayward .pdf.

121. The "U.S. FDA is encouraging the use of RFID for fighting counterfeit drugs. The technology identifies all individual drug packages with the help of RFID readers and RFID tags containing information about the drug's origin, a so called ePedigree (electronic pedigree), which is hard to manipulate." Hanna Ostman et al., Preventing Counlerfeit Drugs with RFID, RFID ARENA (Feb. 7, 2013), http://www.rfidarena.com/2013/2/7/ preventing-counterfeit-drugs-with-rfid.aspx.

122. JohnsByrne BLoc, supra note 115 ("Invisible inks (seen only by black light) can be used for anti-diversion codes on a product's packaging. The invisible codes can be placed in multiple places both inside and outside the carton/package. Invisible technologies for tracking provide companies with the security of knowing whether a product on the shelf is on the 'right' shelf and if it's legitimate."). 
change frequently enough that illicit copiers could not easily keep up.

- Alert potential buyers to be on the look-out for illicit copies. ${ }^{123}$ Do this either by public awareness campaigns about the widespread prevalence of illicit copies for various products, or have the authentic producer website supply information to make potential buyers aware of the risks. ${ }^{124}$

\section{iii. Suggested Measures to Disrupt Persisting Markets}

Persisting markets are most likely to be by de-centralizing enforcement, thus strongly supplementing public law-enforcement methods.

- In an analogy to the treble-damages private enforcement system of U.S. antitrust laws, consumers could be incentivized to report either to a private manufacturer or to a state law enforcement agency whenever the consumer suspects an illicit copying scheme. ${ }^{125}$ In China, rewards are offered to people who report piracy. ${ }^{126}$ Reporting suspicions could be made efficient through smartphone apps that facilitate the easy e-mailing by consumers of photographs of illicit copies and information about the sales channels and distribution mechanisms. ${ }^{127}$

- Such a system need not be expensive-rewarding informants with free examples of the goods they were originally seeking may be sufficient, and the marginal cost to the rightful producer of giving such a reward would be slight. Empowering consumers to report illicit activity easily through their cell phones could have a strong deterrent value as well. Sellers could never be sure when an individual might be a potential IPR enforcement agent.

123. The Alibaba organization maintains a "mystery shopper" system in which counterfeit or low-quality goods purchased online through Alibaba are reported through its network of shoppers working for the seller. Ni Liano, WorLd InTEli.eTLA. Prop. OrG., WIPO/ACE/9/24, Intellectlal. Property Proteciton Practices of Alibaba Grolp Under Thif Inter.ilet Platform-Based Blsiness Model. (2014), http://www.wipo.int/ edocs $/ \mathrm{mdocs} / \mathrm{mdocs} /$ en/wipo_ace_9/wipo_ace_9_24.pdf.

124. Michelle C. Leu, Aulhenticate This: Revampring Serondary Trademark Lialiility Siandards to Address a Worldwide Web of Counterfrits, 26 BeRKF.LFY TrC.H. L.J. 591, 604 (2011) (describing the eBay program permitting companies to post "About Me" page on its website alerting consumers to counterfeits, and the Tiffany Company example).

125. Waltmire, supra note 108 , at 48 ("It is reported that Chinese courts put more weight on written and physical evidence than on oral evidence. When investigators begin with little information, they seek initial information from the public and the internet. In some instances, offering a reward for information can be an effective means of obtaining needed information.") (footnote omitted).

126. I2 Million Yuan Reward Offered for Reporting Illegal Publications, Ptople's DAILY (June 22, 2000), http://en.people.cn/english/200006/22/eng20000622_43718.html ("The Chinese government has offered 12 million yuan (1.4 million U.S. dollars) to reward people who report to local police or departments concerned the production and trading of pornographic and pirated goods and other illegal publications in the past few years.").

127. The Software \& Information Industry Association operates a general public software piracy reporting page. Repart Software Piracy at a Company, Software \& INFo. INDUs. Ass' $N$, https://www.siia.net/piracy/report/report.asp (last visited May 15, 2015). 
- Governments could, through licensing or other regulatory means, enlist the producers of operating systems (e.g., Microsoft, Google, and Apple) to act more strongly as enforcement agents. $^{128}$ Governments could require that operating system producers cooperate with providers of IP protected materialsoftware or digital entertainment-such that codes embedded by rightful IP producers would send use-information to the operating system producer whenever a particular new software was first used on a computer.

\section{The Evolution of PPL Methods and Design Principles}

The integrated PPL method for addressing legal problems, as illustrated by the piracy example, can be applied more globally to Information Age challenges. In that larger context, the PPL methods grow into a new set of design principles that shape the evolution of both PPL and legal system design in a way that more effectively addresses complex problems but also safeguards Western liberal values. Hopefully, offering such a list will contribute to future dialogue and additional research.

The guidelines for re-design of the legal system suggested below are thus directed at both business contexts and public regulatory levels:

- Render legal rights and legal rules intelligible and accessible in design, and transparent as to the process of their creation.

- Decentralize, where possible, the sources and enforcement of contractual provisions and legal norms.

- Respect consensual commercial and social relationships, but ensure that the consent is genuine.

- Structure procedures, assessment, and communication channels so as to enable people to take measures to prevent legal problems from arising, or to contain problems quickly against escalation.

- Honor, where possible, historical relationships and their attendant loyalties and social identities-but always stress tolerance and dignity toward those who are different.

- Augment the power of the law with private incentives, social reinforcement, marketplace choices, and broad participation to assist in law enforcement.

- Diversify possible remedies and involve communities of interest constructively in the implementation of those remedies.

Each of the principles above reflects in some way the exploding communication and informational display capabilities of new technologies. Each principle could guide possible legal innovations so as to resonate positively with the emerging social, informational, and

128. Microsoft allows individuals to report piracy by completing an online reporting form. Reporting Software Piracy, Microsoft, https://www.microsoft.com/en-us/pira $\mathrm{cy} /$ reporting/default.aspx (last visited Nov. 17, 2015). See also Microsoft's anti-piracy information page, Protect Yourself from Piracy, Microsoft, https://www.microsoft.com/enus/piracy/default.aspx (last visited May 15, 2015). 
organizational patterns that are prompted by those same technological developments. Aligning legal innovations to be consistent with changing culture will deepen the popular support on which the Rule of Law depends. Information, knowledge, loyalty, respect, and trust each can reinforce state power in the resolution of legal problems without abandoning the distinctiveness that makes lawyers and legal systems essential to liberal democratic societies. ${ }^{129}$

\section{Conclusion}

The arrival of the Information Age is prompting a re-design of legal systems that may build on, and revitalize, the PPL approach to lawyering. Both levels, the law itself and its everyday practice, can harness the power of cultural trends and social patterns. At each level, design principles can be formulated that seek to strengthen and diversify channels of communications; human relationships; horizontal information creation, classification, and sharing; and procedures for addressing problems in more particularized ways.

In its analysis, this Article straddles the worlds of the practicing lawyer and the broader legal system, much like the business lawyer whom Terrell describes as caught between the "treacherous terrain of the law, and the ... oozing swamp of business." It is tempting to seek the relative comfort of analyzing solely PPL practice, or the law itself. But they are in fact entwined, just as business and law give meaning to each other. Finding stronger connections between individual lawyers and their clients can build the impetus toward a legal system in general that seeks to integrate and reinforce its methods with those of technology, markets, and human motivation and relationships. The connections are easier and more appropriate for some problems than for others, just as PPL works more easily in some client settings than others. But at both layers, the effort to think of traditional legal methods as a sliding scale of procedural partnering, rather than as a rigid container, can lead to stronger effectiveness.

Finally, a sensitive re-design of the balance between legal separation and connection-one more suitable to modern information culture and technologies-can strengthen Western liberalism rather than threaten it. Liberal values are pragmatic, built upon self-doubt and dialogue, rather than ideology and purity. ${ }^{130} \mathrm{~A}$ conversation about its future, and that of the legal systems and economies built upon it, will be both healthy and productive.

129. See Barton, supra note 54, passim.

130. Barton, supri note 14 , at $166-67$. 
